\title{
Variation in Soil Properties on Cassava Production in the Coastal Area of Southern Cross River State, Nigeria
}

\author{
A. S. Gbadegesin \\ Department of Geography, University of Ibadan, Nigeria \\ E-mail: ask4mossabua@yahoo.com
}

M. A. Abua \& J. E. ATU

Department of Geography and Environmental Science, University of Calabar, Nigeria

Received: December 1, 2010 Accepted: December 17, 2010 doi:10.5539/jgg.v3n1p94

\begin{abstract}
This study aimed at identifying the major soil properties determining cassava production. The soil profile pits were dug along the catena. In each of the profile, soil samples were collected at each horizon based on the number of horizon(s) in the profile. Soil samples collected were air-dried, grinded and sieved prior to routine laboratory analysis. In addition, an estimated area of $10,000 \mathrm{~m}^{2}$ cassava plot was gridded into $10 \mathrm{~m}^{2}$ cells and 10 plots randomly selected for vegetative and yield analysis of cassava. The relationship between vegetative and yield parameters of the crops were related to the soil properties using Pearson's product Moment Correlation and Multiple regression analytical techniques. The results revealed that sand fraction are high with means of $88.16 \%$ and $81.98 \%$ surface and subsurface soils in the area. The soils are acid ( $\mathrm{pH}$ range, 5.0-5.8) with low mean values of 5.25 , effective CEC (6.41-6.33 cmol/ $\left.\mathrm{kg}^{-1}\right)$, organic matter (0.34-4.80 percent), total Nitrogen $(0.10-0.45 \%)$. The soil $\mathrm{pH}$, organic matter, exchangeable $\mathrm{K}$, effective $\mathrm{CEC}$, exchange acidity, total nitrogen and pore space with multiple correlation coefficient (R) values of $0.51,0.51,0.50,0.66,0.63,0.60$, and 0.85 respectively, most strongly influenced cassava yield in the study area. The soil could be made productive in terms of crop cultivation if proper management system is advocated.
\end{abstract}

Keywords: Variation, Soil Properties, Cassava Production, Coastal area and Cross River State

\section{Introduction}

Soil is a major component of the environmental system. It is a major resource of the earth with a lot of potential. Infact, soil has been described as the basis of human civilization. This is because; soil supports plants, which provide nutrition for man and his livestock (Faniran and Areola 1978; Summer and Wilding, 2000). Different types of soils occur in various regions under different geological and soil forming processes. For instance, coastal plain soils are formed from sedentary rocks deposited mostly in a Marine environment, which are uplifted and tilt seaward with part being submerged by Atlantic Continental Shelf (Summer, 1994; Abua and Edet, 2007). In Southern Cross River State of Nigeria, coastal plain soils are found along Akpabuyo, Anantigha and Calabar Municipality.

Soil is likely to show great variability in their physical, chemical, biological properties because the soil is a heterogeneous unit. Knowledge of variability of soil properties is very indispensable as this can affect crop yield. A study of the variability trends of soils is essential in order to highlight the soil potentials and enhance their management and productivity (Mahdi et al, 2006; Arnold, 1996).

Anikwe et al (1999) found that the spatial variability of soil properties has effects on crop production across a field. They went further to posit that it is important to be aware of the effect of spatial variability of soil properties when choosing indicator variables of soil quality for crop production. Although, when, how and where to collect soil samples for soil quality determination may differ according to the objective of the assessment being made. They concluded that management history and current inputs should also be considered to ensure valid interpretation of the information.

Although soils are the foundation for production and profit, returns on investment in soil management (except for short-term fertilizer responses) are difficult to quantify and the effects of today's management practices may not 
appear for decades Anikwe (2006). However, while there is growth both in the harvest hectares and the crops produced (cassava production grew by $11.8 \%$ between 1999 and 2004 while hectare harvested grew by $40.4 \%$ ) and the demand still outstrips the supply by a great margin. It is estimated that close to $40 \%$ of Nigerians are still experiencing food insecurity in a country where cultivable land is 72 million hectares, with 34 million hectares (47\%) actually cultivated (Avar and Uza, 2002; Afolabi, 2007).

Aweto and Iyamah (1993) worked on catenary variation of vegetation in swamp forest in South-Western Nigeria. The study revealed that catena developed on coastal plain sands does not exhibit strong spatial differentiation in soil characteristics between its upper middle and lower sections because the area is characterized by low gentle relief with no distinctive hill rising above the general land surface. They concluded that root crops such as yams and cassava cannot be profitably cultivated in the lower slope of the catena characterized by the swamp forest.

Therefore, there is need to devise a method of identifying the crucial soil properties influencing crop production in order to develop a more reliable model between yield of crops and soil properties. This work presents a method of identifying the crucial soil properties influencing crop yields in an area using the cassava crop as an example and the coastal area of southern Cross River State, Nigeria as the study area. In addition, it demonstrates a possible method of overcoming the problem of unreliability of crop yield records in this part of the world where such records are lacking.

\section{Aim and objective}

The aim of the study is to examine variation in soil properties on cassava production on the coastal area of Southern Cross River State. The specific objective is to establish the relationship between soil properties and cassava yield in the study area.

\section{Materials and method}

\subsection{Study area}

The study area is located in Akpabuyo Local Government Area of Cross River State, Nigeria. Akpabuyo Local Government Area is located between Latitudes $4^{0} 45^{\prime} \mathrm{N}$ and $5^{\circ} 10^{\prime} \mathrm{N}$ and Longitudes $8^{0} 20^{\prime} \mathrm{E}$ and $8^{0} 40^{\prime} \mathrm{E}$ of the Greenwich Meridian (Fig. 1). It lies within the tropical rainforest zone of Nigeria. The area is undulating

covering about 102 square kilometers. The mean annual rainfall is about $2500 \mathrm{~mm}$ while the average temperature ranged between $27^{\circ} \mathrm{C}$ to $28^{\circ} \mathrm{C}$ in the prescribed zone. Most of the vegetation in the zone is secondary bush forest because the original vegetation has been tempered via anthropogenic activities.

\subsubsection{Field Studies}

Soil profile pits were dug within each hectare on the farm cultivated with cassava plants at different topographical positions of crest $\left(\mathrm{P}_{1}\right)$, middle slope $\left(\mathrm{P}_{2}\right)$ and valley bottom $\left(\mathrm{P}_{3}\right)$ duly geo-referenced with the aid of a Global positioning system (GPS) (Magellan Spot Track Map GPS). Profiles were dug to the depth of $150 \mathrm{~cm}$ to $200 \mathrm{~cm}$ except where a Water table is struck or an impenetrable layer is encountered. The horizons were delineated and the profiles were described according to the provision of the Soil Survey Staff (2006). Soil samples taken from the different horizons were stored in polythene bags and transported to the laboratory for analysis.

In addition, an estimated area of $10,000 \mathrm{~m}^{2}$ of cassava plot was grided into $10 \mathrm{~m}^{2}$ cells and 10 plots randomly selected for the vegetative and yield analysis. At each sampling unit an areas of $10 \mathrm{~m}^{2}$ was marked out by measuring dimensions of $10 \mathrm{mx} 10 \mathrm{~m}$ with a measuring tape. The number of cassava stands within the $10 \mathrm{~m}^{2}$ area were counted and recorded. All the cassava stands within the marked out areas for the ten sampled quadrats (plots in each of the three farms were harvested and fresh tuber bulked together in a sack and then weighed with a manual weighing balance and the mean weight in kilogramme determined. The leaves were carefully removed from the stems, put in a sack and the fresh weight determined. The cassava stems without leaves were tied together with a rope and fresh weight determined with a weighing balance. The average of each variable measured (fresh tuber weight, leaf weight and stem weight) was calculated from the ten sampling units.

This was repeated for 10 locations within a hectare for each of the three cassava plots. Thereafter, the mean yield was calculated. This was later converted to tones/hectares for each of the plots by multiplying by 10,000 (being cassava population per hectare). The procedure was applied to fresh leave weight and stem weight.

\subsubsection{Laboratory analysis}

The soil samples were air-dried and sieved through a $2 \mathrm{~mm}$ sieve. Particle size was determined by the hydrometer method (Juo, 1979). Soils reaction $(\mathrm{pH})$ was determine in 1:2 soil/water ratio by use of glass electrode $\mathrm{pH}$ metre. Organic Carbon was determined by the Walkley and Black (1934) method while total nitrogen was by the Kjeldale digestion method. Available phosphorus was determined by the Bray and Kurtz No. 1 method. Exchangeable 
(bases) cations were extracted with $\mathrm{IN} \mathrm{NH} \mathrm{N}_{4} \mathrm{OAC}(\mathrm{pH} 7)$; Calcium $(\mathrm{Ca})$ and Magnesium $(\mathrm{Mg})$ were determined by the EDTA titration method while potassium $(\mathrm{K})$ and Sodium $(\mathrm{Na})$ were determine with flame photometer (Black et al., 1965). Exchangeable acidity $\left(\mathrm{H}^{+}\right.$and $\left.\mathrm{Al}^{3+}\right)$ were determined by leaching the soils with IMKCL and titrating aliquots with $0.01 \mathrm{NaOH}$. The bulk density was also determined by the core method (Tel and Hagarly, 1984) using a core sampler and effective cation exchange capacity (ECEC) was evaluated by the summation of exchangeable bases $(\mathrm{Ca}, \mathrm{Mg}, \mathrm{K}$ and $\mathrm{Na})$ and exchange acidity $\left(\mathrm{Al}^{3+}\right.$ and $\left.\mathrm{H}^{+}\right)$. Base saturation percentage was obtained by calculation thus:

$$
\mathrm{B} . \mathrm{S}=\frac{\mathrm{TEB}}{\mathrm{ECEC}} \times 100
$$

Where:

B.S $=$ Base saturation

TEB = Total exchangeable bases;

$\mathrm{ECEC}=$ Effective cation exchange capacity

\subsection{Procedure for data analysis}

Different statistical tools were employed for data analysis and presentation such as descriptive and inferential statistics. Descriptive statistics such as means, range, standard deviation (SD) and coefficient of variability (CV) were used to analyze the data. The coefficient of variability (C.V) is given as:

$$
\text { C.V. }=\frac{\delta}{\overline{\mathrm{X}}} \times 100
$$

Where:

C. V. = Coefficient of variability

$\delta=$ standard Deviation

$\overline{\mathrm{X}}=$ the Mean.

Furthermore, Pearson's Product Moment Correlation and the step-wise multiple regression model were used to investigate the nature of the relationship between the cassava parameters and the soil properties. The essence of using the step-wise multiple regression model is to reduce the number of soil properties that mostly influence cassava yield (vegetative parameters). The Pearson's Product Moment Correlation and Multiple regression Model are given as thus repectively:

$$
\mathrm{r}=\frac{1 / \mathrm{n} \Sigma(\mathrm{x}-\mathrm{x})(\mathrm{y}-\mathrm{y})}{(\delta \mathrm{x})(\delta \mathrm{y})}
$$

Where:

$\mathrm{r}=$ Correlation Coefficient

$\mathrm{x}$ and $\mathrm{y}=$ the variables of interest

$\delta=$ Standard deviation

$\mathrm{y}=$ Crop yield

$\mathrm{x}=$ Soil properties and

$$
\mathrm{y}=\mathrm{a}+\mathrm{b}_{1} \mathrm{x}_{1}+\mathrm{b}_{2} \mathrm{x}_{2}+\mathrm{b}_{3} \mathrm{x}_{3}+\ldots+\mathrm{b}_{\mathrm{j}} \mathrm{x}_{\mathrm{j}}+\mathrm{e}
$$

Where:

$\mathrm{y}$ is the independent variable (soil properties)

a is the intercept

$\mathrm{xj}$ are the dependent variables (cassava yield)

bj are the regression coefficients and e is error term. 


\section{Results and discussion}

The physico-chemical properties of the prescribed soils are discussed in table 1. Profiles were studied in the early part of the rainy season in April, 2007.

\subsection{Physico-chemical characteristics}

The physical and chemical characteristics of the soils of the prescribed area is presented in table 1 . The textures of the soil are predominantly sandy loamy sand and loamy sandy with high sand fraction for both surface and subsurface soils, with mean silt contents below $15 \%$, the soil have weak surface aggregation. In terms of descriptive statistics, the surface and subsurface soils, had a standard deviation of 3.79 and 4.95 with coefficient of variability of $4.30 \%$ and $6.04 \%$ respectively in all the established profiles (Table 1). Such soil may lack adsorptive capacity for basic plant nutrient and may be susceptible to erosion menace. With the absence of rock fragments (boulders) in the subsurface soils, it may permit available water capacity in direct proportion to their volume. The bulk density ranged from 1.0 to $1.70 \mathrm{MgM}^{-3}$ with mean values of $1.18 \mathrm{MgM}^{-3}$ and $1.42 \mathrm{MgM}^{-3}$ respectively in the surface and subsurface soils and its corresponding pore space surface mean value of $55.51 \%$ (range, 50.94-62.26\%). The moisture contents varied from 10.63 to $19.20 \%$ (surface soil) and between 8.19 to $19.42 \%$ (subsurface soils) with means of $16.16 \%$ and $12.18 \%$ in surface and subsurface soils respectively (Table 1).

The soil reactions is acid (range: $\mathrm{P}^{\mathrm{H}}$ 5.0-5.8) (Bready and Weil, 1999) such $\mathrm{P}^{\mathrm{H}}$ condition of the soils could be attributed to the high rainfall exceeding $3500 \mathrm{~mm}$ per annum, could leach out basic cations from the soil solum in the study area. Such soil condition can induce phosphate fixation and reduce the ability of microorganisms to fix atmospheric nitrogen. The standard deviation and coefficient of variability decrease with depth $(\mathrm{SD}=0.24-0.18$; $\mathrm{CV}=4.52-3.46 \%$ ). This may be due to decrease in sand content with depth and an increase of clay fraction with depth in all the pedons examined. Organic matter ranged from 1.82-4.80 and 0.34-2.41 for surface and subsurface soils respectively. Therefore, such level of organic matter content could sustain intensive cassava production and other agronomic crops in the ecological zone. This low level of organic matter content may be attributed to intensive land use via cropping and natural settings. However, standard deviation decreases with depth down the profiles while the coefficient of variability is the reverse (range: $29.69-48.30 \%$ ) from the surface to the subsurface soils in all the profiles studied.

Total nitrogen contents were low (range, 0.10 to the $0.45 \%$ ) with mean values of 0.08 and 0.05 percent for surface and subsurface soils. This level of total nitrogen cannot sustain intensive crop production as values were below 0.45 percent established for productive soils in the zone. This low level of total nitrogen could be attributed to rapid microbial activities, leaching of nitrates and crop removal in the soil of the prescribed study area. Available Phosphorus value were high (range, 4 to $80 \mathrm{MgKg}^{-1}$ ) with mean values of $28 \mathrm{MgKg}^{-1}$ and $41 \mathrm{MgKg}^{-1}$ respectively in the surface and subsurface soils. The standard deviation (range: $18.8-18.0 \mathrm{MgKg}^{-1}$ ) and its corresponding coefficient of variability (range: 64-75.44\%) decreases with depth in the surface and subsurface soils.

Therefore, the soils are rich in phosphorus mineral. Exchangeable bases were generally low with the following ranges of values $\mathrm{Ca}\left(1.00\right.$ to $\left.4.00 \mathrm{cmol} / \mathrm{kg}^{-1}\right) ; \mathrm{Mg}\left(0.40\right.$ to $\left.2.00 \mathrm{cmol} / \mathrm{kg}^{-1}\right) ; \mathrm{K}\left(0.04\right.$ to $\left.0.27 \mathrm{cmol} / \mathrm{kg}^{-1}\right)$ and with means of $2.44 \mathrm{cmol} / \mathrm{kg}^{-1}$ and $\left.2.33 \mathrm{cmol} / \mathrm{kg}^{-1}(\mathrm{SD}=0.73-0.80) \mathrm{CV}=30.05-34.37 \%\right)$ with means of $1.15 \mathrm{cmol} / \mathrm{kg}^{-1}$ and $1.08 \mathrm{cmol} / \mathrm{kg}^{-1} ;(\mathrm{SD}=0.43-0.32 ; \mathrm{CV}=37.72-29.86 \%)$ with means of $0.14 \mathrm{cmol} / \mathrm{kg}^{-1}$ and $0.10 \mathrm{cmol} / \mathrm{kg}^{-1}$ (standard deviation: $0.07-0.06 ; \mathrm{CV}=53.03-55.74 \%) \mathrm{Na}\left(0.03\right.$ to $\left.0.08 \mathrm{cmol} / \mathrm{kg}^{-1}\right)$ with these levels of exchangeable bases, the soils lack adsorptive, capacity for nutrient. The Standard deviation and Coefficient of variability were low in exchangeable Calcium, Magnesium and Sodium excepting exchangeable Potassium $(\mathrm{SD}=0.07$ to 0.06 ; $\mathrm{CV}=53.03$ to $55.74 \%$ ) that was relatively higher albeit increase with depth for the coefficient of variability while the reverse is the case for the standard deviation. The exchangeable acidity values were low as their values were within the moderate range of 2.1 to $4.0 \mathrm{cmol} / \mathrm{kg}^{-1}$ for crop production in the study area. These low values reflect the $\mathrm{pH}$, albeit hydrogen and aluminium irons may be the principal contributors to exchangeable acidity in the soils. Such range of values may not hinder crop production in the ecological zone as reported by Ukpong (1995) who worked in a more acidic soil in the mangrove swamps of South-Eastern Nigeria. The standard deviation and Coefficient of variability $(\mathrm{SD}=0.88-0.42$; $\mathrm{CV}=77.19-36.84 \%$ ) increases with depth down the profile for coefficient of variability while the standard deviation is the reverse.

The Effective Cations Exchange Capacity (ECEC) hardly exceeds $10 \mathrm{cmol} / \mathrm{kg}^{-1}$ ). That is ECEC was generally low $\left(<10 \mathrm{cmol} / \mathrm{kg}^{-1}\right)$ in all the soils (range of 3.98-9.11 $\left.\mathrm{cmol} / \mathrm{kg}^{-1}\right)$ with mean values of $6.41-6.33$ for both surface and subsurface soils respectively. Standard deviation (range: 1.52-1.26) and its corresponding coefficient of variability (range: 23.68-19.85\%) decrease with depth in both surface and subsurface soils down the profiles (Table 1). This range of values less than $10 \mathrm{cmol} / \mathrm{kg}^{-1}$ is indicative that the soils are inherently infertile to sustain intensive crop 
production. With the Mean percentage base saturation values above 60 in both the surface and subsurface soils, nutrients might exist in available forms in soil solution despite the low nutrients reserves in the soil environment.

\subsection{Soil properties to cassava yield parameters}

This section discusses the relationship between the soil properties and cassava yield parameters (tuber, leaves and stem).

The negative and significant relationships between bulk density and moisture content in soils of the study area indicates that increase cassava tuberization leads to a corresponding decrease in bulk density and moisture contents in soils in the study area. However, the negative correlation of bulk density to tuber yield indicates that the more compact the soil becomes, the lower the tuber yield of cassava. Similar result was obtained by Gbadegesin (1996) who worked on soils of savanna belt of South-Western Nigeria using maize yield parameters (leaves, leaf area, number of cobs and stem height). Moreso, the negative correlation of moisture content to cassava tuber yield also suggest that decrease in moisture content could enhance tuber yield, as high moisture content would have adverse effect on tuberization (Table 2 and 3 ).

The positive and significant correlation between soil $\mathrm{pH}$ and the tuber suggests the increase of cassava tuber with increase in soil $\mathrm{pH}$. Implications of the relationships are that at low $\mathrm{pH}$ values, we have high tuber yield, occasioned by low mineralization. Besides, organic matter, exchangeable K, effective CEC (exception of base saturation, $\mathrm{Ca} ; \mathrm{Mg}, \mathrm{Mg}: \mathrm{K}$ and $\mathrm{C}: \mathrm{N}$ ratios) positively and significantly correlate with tuber yield, as an increase in these parameters exert a proportional increase in tuber contents while the reverse is the case for base saturation, $\mathrm{Ca}: \mathrm{Mg} . \mathrm{Mg}: \mathrm{K}$ and C:N ratios whose results negatively though significantly correlated with the crop yield besides, it shows a multiple regression coefficient $\left(\mathrm{R}^{2}\right)$ of 0.78 . A number of studies have reported similar results see for instance studies by Gbadegesin (1996) and Odjugo (2007) similar results relating cassava tuber in savanna belt of South-western Nigeria and some oil producing communities in Delta Sate and its environs.

The positive and significant correlation between soil $\mathrm{pH}$, total nitrogen, carbon-nitrogen ratio, effective CEC, exchangeable $\mathrm{Ca}$ and exchange acidity to cassava leaves-yield imply increase of these parameters with attendant increase in the leaves yield in the area under study with a multiple regression coefficient $\left(R^{2}\right)$ of 0.50 . These findings also agreed with the results obtained by Gbadegesin (1996) on vegetative parameters of maize grains in the savanna region of South-western Nigeria. Others, base saturated and $\mathrm{Ca}: \mathrm{Mg}$ ratio negatively though significantly correlated with the aforementioned variables which contributed to leaves yield of cassava (Table 4 and 2).

The significant and negative correlation between silt, bulk density and moisture content in the study area indicates that increase in stem yield leads to a decrease in the parameters examined. The estimates show a multiple regression coefficient $\left(\mathrm{R}^{2}\right)$ of 0.87 and an intercept of -194.13 . Pore space positively and highly significantly correlated with the stem-yield, as increase in pore space lead to an increase in stem yield (Table 5).

\section{Conclusion}

Variations in soil properties influencing cassava production were examined using correlation and multiple regression statistical tools. Results showed that soil $\mathrm{pH}$, organic matter, exchangeable $\mathrm{K}$ and effective $\mathrm{CEC}$ with correlation coefficient values $(\mathrm{R})$ of $0.51,0.51,0.50$ and 0.66 respectively significantly influenced cassava yield particularly at the surface horizon in the study area. Other soil properties that contributed to cassava yield include exchange acidity, total nitrogen and pore space with $(\mathrm{R})$ values of $0.63,0.60$, and 0.85 respectively. The physical and chemical properties of the soils are dissimilar in many respects. The soils could be made productive in terms of crop cultivation if proper management systems such as liming and fertilizer application is advocated.

\section{References}

Abua, M. A. \& Edet, E. O. (2007). Morphological and physico-chemical characteristics of coastal plain soils of southern Cross Rivers State-Nigeria. Nigeria Geographical Journal, 5(1), 109-114.

Afolabi, J. F. (2007). Agriculture in Nigeria today and tomorrow. Nigeria Geographical Journal, 5(1), 82-101.

Anikwe, M. A. N, \& M. E. Obi. (1999). evaluation of an index model for quantifying the productivity of soils in southeastern Nigeria using maize as a test crop. Journal of Agriculture and Environment, 1, 80-89.

Arnold, R. W. (1996). Soil Survey Reliability: Minimizing the Consumer's risk Pp 13-20 in W. G. Nettleton, A. G. Hornsby, R. B. Broen, \& T. L. Coleman (eds), Data Reliability and Risk Assessment in Soil Interpretations. SSSA Spec. Publ. 47, SSSA, Madison, WI.

Avav, T. \& Uza, D. V. (2002). Agriculture, Atlas of Nigeria, Paris Les editions J. A. 92-95. 
Aweto, A. O. \& Iyamah, C. C. (1993). Catenary variations of vegetation in a swamp forest in South Western Nigeria. International Journal of Environmental Studies, 43.

Cox, M. S., Gerard, P. D., Wardlaw, M. C. \& Abshire, M. J. (2003). Variability of Selected Soil Properties and Their Relationships with Soybean Yield. Soil Science Society of America Journal, 67, 1296-1302. doi:10.2136/sssaj2003.1296, http://dx.doi.org/10.2136/sssaj2003.1296

Enwezor, W. O., Udo, E. J. \& Sobulo, R. A. (1981). Fertility status and productivity of the "Acid sands". In “Acid Sands” of southern Nigeria. Soil Science Society Nigerian, Spectrum Publication Monograph, 1, 56-73.

Gbadegesin, A. S. (1996). A method of identifying soil properties influencing crop yield: the examples of maize in the savanna Belt of South-western Nigeria. Geoforum, 17(1), 109-118. doi:10.1016/0016-7185(86)90016-3, http://dx.doi.org/10.1016/0016-7185(86)90016-3

Johnson, R. M., Downer, R. G., Bradow, J. M., Bauer, P. J. \& Sadler, E. J. (2002). Variability in Cotton Fiber Yield, Fiber Quality, and Soil Properties in a South-East Coastal Plain. Agronomy Journal, 94, 1305-1316. doi:10.2134/agronj2002.1305, http://dx.doi.org/10.2134/agronj2002.1305

Kosmas, C., Gerontidis, S., Marathianou, M., Detsis, B., Zafiriou, T., Nan Muysen, Govers, W. G., Quine, T. \& K. Vam Oost, (2001). The Effects of Tillage Displaced Soil on Soil Properties and Wheat Biomass. Soil Tillage Research, 58, 31-44. doi:10.1016/S0167-1987(00)00175-6, http://dx.doi.org/10.1016/S0167-1987(00)00175-6

Kravchenko, A. N. \& Bullock, D. G. (2000). Correlation of Corn and Soybean Grain Yield with Topography, and Soil. Agronomy Journal, 95, 1132-1139. doi:10.2134/agronj2003.1132, http://dx.doi.org/10.2134/agronj2003.1132

Mahdi, A. \& Mark, H. (2006). Integrated Crop Management; Field Soil Variability and Its Impact on Crop Stand Uniformity: Iowa State University, Iowa, U.S.A.

Nnamani, I. C. O. (2002). The influene of Meterological factors on the yield of selected Ecosystem. 12(3), 106-120.

Odjugo, P. A. (2007). Some Effects of Gas Flaring on the Microclimate of yam and Cassava Production in Erhorike and Environs, Delta State, Nigeria. Nigeria Geographical Journal, 5(1), 43-54.

Papiernik, S. K., Lindstrom, M. J., Schumacher, J. A., Farenhorts, A, stephens, K. D. \& Schumachre, T. E. (2005). Variation in soil properties and crop yield across an eroded Prairie landscape. Journal of Soil and Water conservation, 60(6).

Schumacher, T. E., Lindstrom, M. J., Schumacher, J. A. \& Lemme, G.D. (1999). modeling spatial variation in productivity due to tillage and water erosion. Soil Tillage Research, 51, 331-339.

Seybold, C. A., Herrick, J. E., Brejda, J. J. (1999). Soil resilience: a fundamental component of soil quality. Soil Science, 164, 224-234.

Soil Survey Staff. (2006). Keys to Soil Taxonomy. Soil Management Support Services (5 ${ }^{\text {th }}$ ed.). Technical Monograph, 19 Blackburge, Virginia.

Summer, M. E. \& Wilding, L. P. (2000). Introduction. In: A handbook of soil science (M.E. Summer Ed.) CRC Press. Boca Raton USA.

Ukpong, I. E. (1995). Vegetation and Soil acidity of a mangrove swamps in South-Eastern Nigeria. Soil use and management, 11, 141-14. 
Table 1. Summary results showing variations in physico-chemical characteristics of soils samples in Akpabuyo Local Government Area, Cross River State

\begin{tabular}{|c|c|c|c|c|c|c|}
\hline \multirow[t]{2}{*}{ Parameter } & \multirow{2}{*}{$\begin{array}{l}\text { Depth } \\
(\mathrm{cm})\end{array}$} & \multicolumn{4}{|c|}{ Akpabuyo Soils } & \multirow{2}{*}{$\begin{array}{c}\text { Maximum Permissible } \\
\text { Limit }\end{array}$} \\
\hline & & Range & Mean & SD & CV (\%) & \\
\hline \multicolumn{7}{|l|}{ A) Physical Parameters: } \\
\hline \multirow[t]{2}{*}{ (i) Sand (\%) } & $\mathrm{S}$ & $78.54-91.56$ & 88.56 & 3.79 & 4.30 & NL \\
\hline & SS & $71.84-89.84$ & 81.98 & 4.98 & 6.04 & NL \\
\hline \multirow[t]{2}{*}{ (ii) Silt (\%) } & $\mathrm{S}$ & $1.88-8.87$ & 4.63 & 1.96 & 42.33 & NL \\
\hline & SS & $3.88-11.78$ & 6.35 & 1.99 & 31.34 & NL \\
\hline \multirow[t]{2}{*}{ (iii) Clay (\%) } & $\mathrm{S}$ & $4.44-19.58$ & 7.54 & 4.56 & 60.48 & NL \\
\hline & SS & $6.38-18.38$ & 11.68 & 3.41 & 29.20 & NL \\
\hline \multirow[t]{2}{*}{ (iv) Textural Class } & $\mathrm{S}$ & $\mathrm{s}, \mathrm{ls}, \mathrm{sl}$ & - & - & - & - \\
\hline & SS & $\mathrm{sl}, \mathrm{ls}, \mathrm{s}$ & - & - & - & - \\
\hline \multirow[t]{2}{*}{ (v) Bulk Density $\left(\mathrm{MgM}^{-3}\right)$} & $\mathrm{S}$ & $1.00-1.30$ & 1.18 & 0.12 & 10.21 & $\mathrm{NL}$ \\
\hline & SS & $1.00-1.70$ & 1.42 & 0.19 & 13.38 & NL \\
\hline \multirow[t]{2}{*}{ (v) Pore Space (\%) } & $\mathrm{S}$ & $50.94-62.26$ & 55.51 & 4.55 & 8.20 & NL \\
\hline & SS & $35.85-62.26$ & 46.52 & 7.13 & 15.32 & NL \\
\hline \multirow[t]{2}{*}{ (vii) Moisture Contents (\%) } & $\mathrm{S}$ & & & & & \\
\hline & SS & & & & & \\
\hline \multicolumn{7}{|l|}{ B) Chemical Parameters: } \\
\hline \multirow[t]{2}{*}{ (i) $\mathrm{PH}\left(\mathrm{H}_{2} \mathrm{O}\right)$} & $S$ & $5.0-5.8$ & 5.3 & 0.24 & 4.52 & $5.1-6.5$ \\
\hline & SS & $5.0-5.8$ & 5.2 & 0.18 & 3.46 & \\
\hline \multirow[t]{2}{*}{ (ii) $\mathrm{EC}\left(\mathrm{dSm}^{-1}\right)$} & $\mathrm{S}$ & $0.030-0.088$ & 0.054 & 0.021 & 38.98 & $2-4 \mathrm{dSm}^{-1+}$ \\
\hline & SS & $0.011-0.078$ & 0.023 & 0.014 & 59.96 & \\
\hline \multirow[t]{2}{*}{ (iii) Org. M (\%) } & $\mathrm{S}$ & $1.82-4.80$ & 3.83 & 0.54 & 29.69 & $2.0^{++}$ \\
\hline & SS & $0.34-3.08$ & 2.85 & 0.41 & 48.30 & \\
\hline \multirow[t]{2}{*}{ (iv) Total N (\%) } & $\mathrm{S}$ & $0.05-0.11$ & 0.08 & 0.02 & 23.75 & $0.20 \%{ }^{++}$ \\
\hline & SS & $0.01-0.09$ & 0.05 & 0.02 & 36.37 & \\
\hline \multirow[t]{2}{*}{ (v) Avail. $\mathrm{P}\left(\mathrm{MgKg}^{-1}\right)$} & $\mathrm{S}$ & $10-63$ & 28 & 18.08 & 64.57 & $2.0 \mathrm{MgKg}^{-1+++}$ \\
\hline & SS & $4-80$ & 41 & 18 & 44 & \\
\hline \multicolumn{7}{|l|}{ Exchangeable] Bases $\left(\mathrm{cmolkg}^{-1}\right)$ : } \\
\hline \multirow[t]{2}{*}{ (vi) $\mathrm{Ca}$} & $\mathrm{S}$ & $1.40-3.40$ & 2.44 & 0.73 & 30.05 & $10-20 \mathrm{cmolkg}^{-1+++}$ \\
\hline & SS & $1.00-4.00$ & 2.33 & 0.80 & 34.37 & \\
\hline \multirow[t]{2}{*}{ (vii) $\mathrm{Mg}$} & $\mathrm{S}$ & $0.50-2.00$ & 1.15 & 0.43 & 37.72 & $3-8 \mathrm{cmolkg}^{-1+++}$ \\
\hline & SS & $0.40-1.80$ & 1.08 & 0.32 & 29.86 & \\
\hline \multirow[t]{2}{*}{ (viii) $\mathrm{K}$} & $\mathrm{S}$ & $0.06-0.27$ & 0.14 & 0.07 & 53.03 & $0.6-1.2 \mathrm{cmolkg}^{-1+++}$ \\
\hline & SS & 0.040 .23 & 0.10 & 0.06 & 55.74 & \\
\hline \multirow[t]{2}{*}{ (ix) $\mathrm{Na}$} & $\mathrm{S}$ & $0.04-0.07$ & 0.06 & 0.11 & 18.63 & $0.7-1.2 \mathrm{cmolkg}^{-1+++}$ \\
\hline & SS & $0.03-0.08$ & 0.05 & 0.02 & 31.29 & \\
\hline Exchange Acidity $\left(\mathrm{cmolkg}^{-1}\right)$ : & & & & & & $4.1 \mathrm{cmolkg}^{-1+++}$ \\
\hline x) $\mathrm{Al}^{3+}$ & $\mathrm{S}$ & $1.05-2.81$ & 1.69 & 0.53 & 31.41 & $2.1-4 \mathrm{cmolkg}^{-1+++}$ \\
\hline
\end{tabular}




\begin{tabular}{|l|l|c|c|c|c|c|}
\hline & SS & $0.60-2.85$ & 1.65 & 0.59 & 36.03 & \\
\hline (xi) H & S & $0.30-3.20$ & 1.14 & 0.88 & 77.19 & - \\
\hline & SS & $0.45-1.90$ & 1.14 & 0.42 & 36.84 & \\
\hline (xii) ECEC $\left(\mathrm{cmolkg}^{-1}\right.$ ) & S & $4.54-9.03$ & 6.41 & 1.52 & 23.68 & $10 \mathrm{cmolkg}^{-1+++}$ \\
\hline & SS & $3.98-9.11$ & 6.33 & 1.26 & 19.85 & \\
\hline (xiii) Base Saturation (\%) & S & $39-75$ & 59 & 12.61 & 21.37 & $60-80 \%{ }^{+++}$ \\
\hline & SS & $36-74$ & 55 & 10.32 & 18.76 & \\
\hline C) Fertility Indices: & & & & & & \\
\hline (i) Ca:Mg Ratio & S & $1.50-2.86$ & 2.25 & 0.48 & 21.16 & $3: 1-5: 1^{* *}$ \\
\hline & SS & $1.25-2.86$ & 2.15 & 0.37 & 17.14 & \\
\hline (ii) Mg:K Ratio & S & $2.61-22.22$ & 10.20 & 6.77 & 66.36 & $1: 2^{* *}$ \\
\hline & SS & $1.74-28.00$ & 13.94 & 6.87 & 49.28 & \\
\hline (iii) C:N Ratio & S & $17-25$ & 22 & 2.78 & 12.64 & $25^{*}$ \\
\hline & SS & $12-25$ & 18 & 3.92 & 21.75 & \\
\hline
\end{tabular}

Notes:

$\mathrm{S}=$ Surface soils; SS = Subsurface soils; $\mathrm{S}_{1}=$ Sand; Ls = Loamy sand; sl = Sandy loam;

$+=$ Miller and Donahue (1995); ++ = FPDD (1990); +++ = Holland et al., (1989)

ECEC $=$ Effective cation exchange capacity $\quad *=$ Paul and Clark (1989); $* *=$ Landon (1991)

$\mathrm{EC}=$ Electrical conductivity; $\mathrm{NL}=$ No limit

Table 2. Summary showing yield parameters of fresh weight local cassava cultivar in Akpabuyo, Cross River State (Akpabuyo study site)

\begin{tabular}{|c|c|c|c|c|c|c|c|c|c|c|c|c|}
\hline & \multicolumn{4}{|c|}{ Tubers } & \multicolumn{4}{|c|}{ Leaves (kg) } & \multicolumn{4}{|c|}{ Stems (kg) } \\
\hline Profiles & Range & $\mathrm{x}$ & $\mathrm{SD}$ & $\begin{array}{l}\text { CV } \\
(\%)\end{array}$ & Range & $\mathrm{x}$ & $\mathrm{SD}$ & $\begin{array}{l}\text { CV } \\
(\%)\end{array}$ & Range & $\mathrm{x}$ & $\mathrm{SD}$ & $\begin{array}{l}\text { CV } \\
(\%)\end{array}$ \\
\hline $\mathrm{P}_{1}$ & $10.02-22.02$ & 15.54 & 4.28 & 27.54 & $1.04-3.02$ & 1.95 & 0.72 & 36.92 & $9.00-13.80$ & 11.11 & 1.62 & 14.58 \\
\hline $\mathrm{P}_{2}$ & $4.24-7.08$ & 6.06 & 0.90 & 14.85 & $0.08-2.02$ & 1.25 & 0.42 & 33.60 & $1.08-6.02$ & 3.57 & 1.80 & 50.42 \\
\hline $\mathrm{P}_{3}$ & $9.00-13.28$ & 10.96 & 1.59 & 14.51 & $1.00-2.24$ & 1.66 & 0.52 & 31.33 & $2.04-5.00$ & 3.33 & 1.00 & 30.03 \\
\hline Range & $4.24-22.02$ & & & & $0.80-3.02$ & & & & $1.08-13.80$ & & & \\
\hline $\mathrm{x}$ & 10.85 & & & & 1.62 & & & & 6.00 & & & \\
\hline SD & 1.90 & & & & 1.27 & & & & 1.41 & & & \\
\hline CV (\%) & 63.33 & & & & 78.39 & & & & 23.50 & & & \\
\hline
\end{tabular}


Table 3. Summary of multiple-regression results with cassava tuber-yield as dependent variable in Akpabuyo

\begin{tabular}{|l|l|l|l|}
\hline Independent variables & $\begin{array}{l}\text { Regression } \\
\text { coefficient }\end{array}$ & Standard error of coefficient & Correlation coefficient (R) \\
\hline \multicolumn{5}{|c|}{ Physical properties } \\
\hline Bulk density & -62.68 & 56.19 & $-0.62^{*}$ \\
\hline Moisture content & -3.13 & 1.58 & $-0.81^{* *}$ \\
\hline $\begin{array}{l}\text { Multiple regression } \\
\text { coefficient (R })\end{array}$ & 0.78 & & \\
\hline intercept value & -29.89 & & \\
\hline \multicolumn{5}{|l|}{ chemical properties } \\
\hline $\mathrm{P}^{\mathrm{h}}$ & 145.02 & 246.52 & $0.51^{*}$ \\
\hline Organic matter & 29.62 & 49.71 & $0.51^{*}$ \\
\hline Exchangeable k & 571.64 & 997.16 & $0.50^{*}$ \\
\hline ECEC & 16.49 & 13.45 & $0.66^{*}$ \\
\hline Bs & -0.56 & 0.67 & $-0.51^{*}$ \\
\hline Ca: $\mathrm{M}$ & -31.86 & 21.80 & $-0.71^{* *}$ \\
\hline Mg: K & -1.92 & 1.52 & -0.65 \\
\hline C:N & -2.93 & 3.30 & -0.53 \\
\hline $\begin{array}{l}\text { Multiple regression } \\
\text { Coefficient }\left(\mathrm{R}^{2}\right)\end{array}$ & 0.54 & & \\
\hline intercept value & 92.61 & & \\
\hline
\end{tabular}

$*=5 \%$ level $(95$ percent $) ; * *=1 \%(99$ percent $)$

Table 4. Summary of multiple-regression result with cassava leaves-yield as dependent variable in Akpabuyo

\begin{tabular}{|c|c|c|c|}
\hline Independent variables & $\begin{array}{l}\text { Regression } \\
\text { coefficient }\end{array}$ & $\begin{array}{l}\text { Standard error of } \\
\text { coefficient }\end{array}$ & $\begin{array}{l}\text { Correlation coefficient } \\
\text { (R) }\end{array}$ \\
\hline \multicolumn{4}{|c|}{ Chemical properties } \\
\hline $\mathrm{p}^{\mathrm{h}}$ & 4.01 & 43.62 & $0.66^{*}$ \\
\hline Total Nitrogen & 33.26 & 59.02 & $0.60^{*}$ \\
\hline Base saturation & -0.036 & 0.046 & $-0.62 *$ \\
\hline $\mathrm{C}: \mathrm{N}$ & 0.096 & 0.136 & $0.58^{*}$ \\
\hline Ca: Mg & -1.90 & 2.26 & $-0.64 *$ \\
\hline Mg: k & -0.127 & 0.16 & $-0.61 *$ \\
\hline ECEC & 0.37 & 0.35 & $0.61^{*}$ \\
\hline $\mathrm{Ca}$ & -0.69 & 0.55 & $-0.66^{*}$ \\
\hline Exch. Acidity & 0.59 & 0.53 & $0.63 *$ \\
\hline $\begin{array}{l}\text { multiple regression coefficient } \\
\left(\mathrm{R}^{2}\right)\end{array}$ & 0.50 & & \\
\hline intercept value & -16.58 & & \\
\hline
\end{tabular}

$*=5 \%$ level $(95$ percent $) * *=1 \%$ (99percent) 
Table 5. Summary of multiple-regression result with cassava stem-yield

\begin{tabular}{|l|l|l|l|}
\hline Independent variables & Regression coefficient & $\begin{array}{l}\text { Standard error of } \\
\text { coefficient }\end{array}$ & $\begin{array}{l}\text { Correlation coefficient } \\
(\mathrm{R})\end{array}$ \\
\hline \multicolumn{3}{|c|}{ Physical properties } \\
\hline Silt & -1.679 & 1.53 & -0.62 \\
\hline Bulk density & -40.93 & 25.62 & $-0.72^{* *}$ \\
\hline Pore space & 1.91 & 0.95 & $0.85^{* *}$ \\
\hline Moisture content & -0.75 & 0.72 & $-0.60^{*}$ \\
\hline $\begin{array}{l}\text { multiple regression } \\
\left.\text { coefficient (R }{ }^{2}\right)\end{array}$ & 0.87 & & \\
\hline Intercept value & -194.13 & & - \\
\hline Chemical properties: & - & - & - \\
\hline
\end{tabular}

$*=5 \%$ level $(95$ percent $) ; *=1 \%(99$ percent $)$

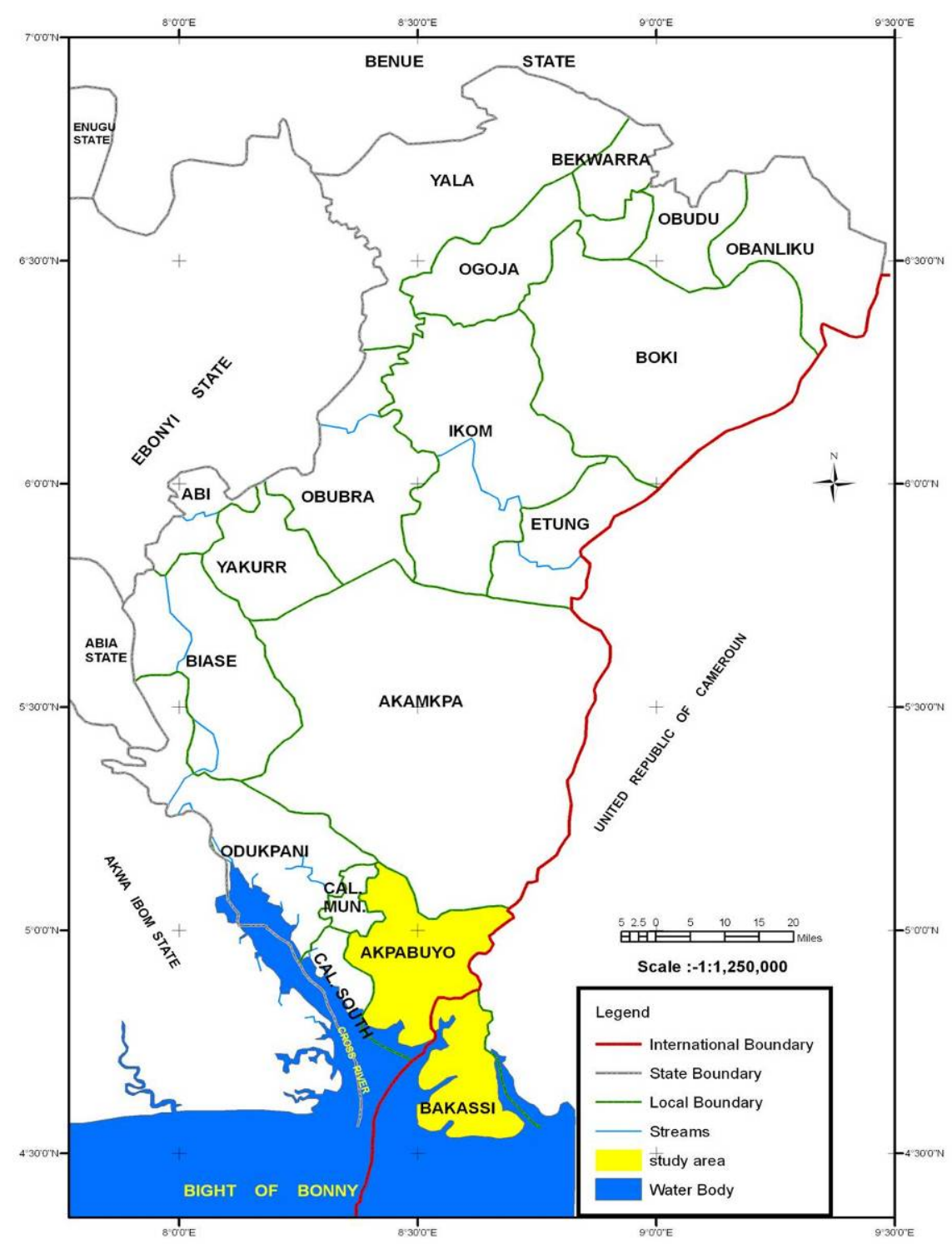

Figure 1 . The study area 